\title{
The Impact of Budget Participation towards Managerial Performance: Job Satisfaction and Perception of Innovation as the Intervening Variables (A Case Study for the Regional District Organization (OPD), Districts of Kudus)
}

\author{
Nanik Ermawati \\ nanik.ermawati@umk.ac.id \\ Program Studi Akuntansi, Fakultas Ekonomi dan Bisnis \\ Universitas Muria Kudus \\ Diah Ayu Susanti \\ Universitas Muria Kudus \\ Zamrud Mirah Delima \\ Universitas Muria Kudus
}

\begin{abstract}
The preparation of the budget for the Regional District Organization (OPD) of the Kudus Regency adopted a budget participation model that involved OPD employees from the head of the OPD to the staff. With the involvement of OPD employees in preparing this budget, it can provide improved managerial performance of OPD employees in their work. But there are several other factors that can improve performance, including job satisfaction and perception of innovation. Therefore in this study will be explained the effect of budget participation on managerial performance through the perception of innovation and job satisfaction as an intervening variable in the regional device organization in Kudus Regency. This research was conducted by questionnaire method through data collection techniques by giving a set of questions to respondents. Questionnaires were given to OPD employees consisting of heads of regional apparatus organizations, field heads, section heads and staff. The test tool used in this study is Path path analysis. The results showed that budgetary participation, job satisfaction, innovation perception had an effect on managerial performance, budget participation had an effect on job satisfaction and perceptions of innovation, but job satisfaction and innovation perception were not able to mediate the influence of budget participation on managerial performance.
\end{abstract}

Keywords: Budget Participation, Managerial Performance, Perception of Innovation, Job Satisfaction

\begin{abstract}
Abstrak
Penyusunan anggaran pada Organisasi Perangkat Daerah (OPD) Kabupaten Kudus menerapkan model partisipasi anggaran yaitu melibatkan pegawai OPD dari kepala OPD sampai dengan staff. Dengan adanya keterlibatan pegawai OPD dalam menyusun anggaran ini dapat memberikan peningkatan kinerja manajerial pegawai OPD dalam bekerja. Namun ada beberapa faktor lain yang dapat meningkatkan kinerja tersebut antara lain kepuasan kerja dan persepsi inovasi. Oleh karena itu pada penelitian ini akan dijelaskan pengaruh partisipasi
\end{abstract}


anggaran terhadap kinerja manajerial melalui persepsi inovasi dan kepuasan kerja sebagai variabel intervening pada organisasi perangkat daerah di Kabupaten Kudus. Penelitian ini dilakukan dengan metode kuesioner melalui teknik pengambilan data dengan memberikan seperangkat pertanyaan kepada responden. Kuesioner diberikan kepada pegawai OPD yang terdiri dari kepala organisasi perangkat daerah, kepala bidang, kepala seksi dan staff. Alat uji yang digunakan dalam penelitian ini adalah analisis jalur Path. Hasil penelitian menunjukkan bahwa partisipasi anggaran, kepuasan kerja, persepsi inovasi berpengaruh terhadap kinerja manajerial, partisipasi anggaran berpengaruh terhadap kepuasan kerja dan persepsi inovasi, tetapi kepuasan kerja dan persepsi inovasi tidak mampu memediasi pengaruh antara partisipasi anggaran terhadap kinerja manajerial.

Kata Kunci: Partisipasi Anggaran, Kinerja Manajerial, Persepsi Inovasi, Kepuasan Kerja

\section{PENDAHULUAN}

Sistem penganggaran daerah di Indonesia diatur dalam Kepmendagri Nomor 13 tahun 2006. Regulasi tersebut menjelaskan tentang pedoman dalam rancangan Anggaran Pendapatan dan Belanja Daerah (APBD) yang dilaksanakan oleh tim anggaran eksekutif bersama-sama unit organisasi perangkat daerah (unit kerja). Anggaran pada sektor pemerintahan membutuhkan proses terkait berupa alokasi jumlah dana, kemudian dari dana tersebut akan digunakan untuk program yang merupakan dana milik rakyat. Hal ini terjadi perbedaan antara anggaran sektor publik dan anggaran sektor swasta. Anggaran sektor publik akan disusun dan dipublikasikan kepada rakyat, karena anggaran dari sektor publik adalah hasil kontribusi dari pajak, retribusi, laba perusahaan daerah atau negara, pinjaman pemerintah berupa utang luar negeri dan obligasi.

Anggaran adalah perencanaan yang disusun untuk menentukan estimasi kinerja yang hendak dicapai selama periode waktu tertentu yang dinyatakan dalam ukuran financial (Mardiasmo, 2002). Anggaran sering digunakan untuk menilai kinerja para manajer. Bonus, kenaikan gaji, dan promosi adalah semua hal yang dipengaruhi oleh kemampuan seorang manajer untuk mencapai atau melampaui tujuan yang direncanakan (Hansen dan Mowen, 2004). Terdapat tiga pendekatan dalam proses penyusunan anggaran menurut Anthony dan Govindrajan (2005), yaitu top-down (pendekatan dari atas ke bawah), bottom-up (pendekatan dari bawah ke atas), dan pendekatan partisipasi. Dalam pendekatan partisipasi ini, diperlukan kerjasama dari berbagai tingkat manajemen untuk mengembangkan rencana anggaran.

Dalam pendekatan partisipatif, pemerintah daerah yang ikut berpartisipasi dalam proses penganggaran diperlukan komunikasi antara kepala OPD dengan kepala bidang, kepala seksi bahkan staff untuk saling memberikan informasi terutama yang bersifat informasi lokal karena pihak staff lebih mengetahui kondisi langsung yang ada di lapangan. Partisipasi penyusunan anggaran sangat erat hubungannya dengan kinerja aparat pemerintah daerah, karena kinerja aparat pemerintah dapat dilihat berdasarkan partisipasi aparat pemerintah dalam menyusun anggaran (Mahoney dalam Leach-Lopez et al., 2007). Menurut Fitrianti dan Marbawi (2013) ada beberapa faktor yang mempengaruhi kinerja manajerial yaitu partisipasi anggaran, kepuasan kerja dan persepsi inovasi.

Partisipasi anggaran merupakan proses penyusunan anggaran yang melibatkan pihak pegawai OPD untuk ikut serta dalam penyusunan anggaran. Pihak pegawai OPD dalam menyusun anggaran merasa pendapatnya dihargai oleh pihak pimpinan, Sehingga pegawai OPD merasa puas terhadap pekerjaanya karena keterlibatannya diakui dan dihargai dalam organisasi. Selanjutnya ketika pegawai OPD itu merasa puas atas pekerjaannya maka nilai kinerja akan meningkat. Hal ini sejalan dengan penelitian yang telah dilakukan oleh Fitrianti 
dan Marbawi (2013). Namun penelitian ini tidak sejalan dengan penelitian yang telah dilakukan oleh Sukmantari dan Wirasedana (2015).

Ermawati (2012) juga menemukan bukti bahwa kinerja manajerial dipengaruhi oleh persepsi inovasi. Persepsi inovasi menggambarkan sejauh mana anggapan diri mereka inovatif (Ermawati, 2012). Para pemimpin akan lebih termotivasi dalam melaksanakan pekerjaannya ketika ide-ide mereka dihargai oleh organisasi. Hal tersebut akan meningkatkan inovasi-inovasi dalam pekerjaan mereka (Ermawati, 2012). Selama ini inovasi terbatas pada sebuah hasil karya atau ciptaan saja, akan tetapi sekarang ini inovasi berkembang sesuai dengan perubahan zaman. Inovasi mampu memberikan kajian-kajian yang bersifat empiris, sehingga sering digunakan untuk hal-hal diluar hasil karya. Seorang pemimpin memerlukan inovasi untuk mengembangkan karirnya, sehingga banyak anggapan bahwa persepsi inovasi masih berkutat pada peran manajer atau pemimpin untuk mengaplikasikan peran kepemimpinannya didalam menjalankan tugas.

Pegawai OPD yang terlibat dalam menyusun Rencana Kerja dan Anggaran akan menimbulkan ide/inovasi yang bagus demi kemajuan organisasi. Dengan adanya inovasi yang bagus sehingga kinerja manajer juga bagus dan prestasi manajer juga meningkat. Borins (2001) mengemukakan adanya interaksi antara partisipasi anggaran, persepsi inovasi, dan attention to detail akan menyebabkan meningkatnya kinerja manajerial. Hasil penelitian tersebut menunjukkan bahwa manajer yang memiliki persepsi inovasi yang tinggi akan meningkatkan kinerja. Manajer yang memiliki persepsi inovasi yang tinggi akan membuatnya lebih inovatif dan kreatif dalam menjalankan pekerjaannya sehingga kinerja akan meningkat. Damanpour.et.al (1989) menemukan bukti bahwa inovasi berpengaruh terhadap kinerja manajerial. Borins (2001) menemukan bukti bahwa inovasi tergantung kerjasama antarorganisasi ketika memecahkan masalah.

Berdasarkan riset gap di atas, maka perlu dilakukan penelitian kembali dengan judul Pengaruh Partisipasi Anggaran Terhadap Kinerja Manajerial: Kepuasan Kerjadan Persepsi Inovasi Sebagai Variabel Intervening (Studi Kasus pada Organisasi Perangkat Daerah (OPD) Kabupaten Kudus). Rumusan pertanyaan penelitian ini adalah:

1. Apakah partisipasi anggaran berpengaruh terhadap kinerja manajerial OPD Kabupaten Kudus?

2. Apakah partisipasi anggaran berpengaruh terhadap kepuasan kerja OPD Kabupaten Kudus?

3. Apakah partisipasi anggaran berpengaruh terhadap persepsi inovasi OPD Kabupaten Kudus?

4. Apakah kepuasan kerja berpengaruh terhadap kinerja manajerial OPD Kabupaten Kudus?

5. Apakah persepsi inovasi berpengaruh terhadap kinerja manajerial OPD Kabupaten Kudus?

6. Apakah kepuasan kerja memediasi pengaruh antara partisipasi anggaran dan kinerja manajerial OPD Kabupaten Kudus?

7. Apakah persepsi inovasi memediasi pengaruh antara partisipasi anggaran dan kinerja manajerial OPD Kabupaten Kudus?.

\section{TINJAUAN PUSTAKA}

\section{Partisipasi Penyusunan Anggaran}

Partisipasi penyusunan anggaran merupakan ciri dari penyusunan anggaran yang menekankan kepada partisipasi aparat pemerintah daerah untuk mempertanggungjawabkan proses penyusunan anggaran. Sedangkan anggaran menurut Munandar (2000) adalah suatu rencana yang disusun secara sistematis yang meliputi seluruh kegiatan pemerintahan yang 
dinyatakan dalam unit (kesatuan) moneter dan berlaku untuk jangka waktu (periode) tertentu yang akan datang.

\section{Kepuasan Kerja}

Robbins (2003) istilah kepuasan kerja merujuk kepada sikap umum seorang individu terhadap pekerjaan yang dilakukannya. Jika seorang individu memiliki tingkat kepuasan kerja yang tinggi maka hal tersebut akan menunjukkan sikap yang positif terhadap kinerja itu sendiri. Namun apabila seorang individu tidak puas dengan pekerjaannya maka hal tersebut menunjukkan sikap yang negatif terhadap pekerjaan itu. Karena pada umumnya apabila seseorang berbicara mengenai sikap aparat pemerintah mereka selalu mengkaitkannya dengan kepuasan kinerja.

\section{Persepsi Inovasi}

Persepsi inovasi manajer menggambarkan sejauh mana para manajer menganggap diri mereka inovatif (Ermawati, 2012). Para manajer akan lebih termotivasi dalam melaksanakan pekerjaannya ketika ide-ide mereka dihargai oleh organisasi. Hal tersebut akan meningkatkan inovasi-inovasi dalam pekerjaan mereka. Manajer yang memiliki persepsi inovasi yang tinggi akan memiliki kualitas kerja yang lebih baik pula.

\section{Kinerja Manajerial}

Supomo (1998) dalam Kurnia (2004) menyatakan bahwa kinerja dikatakan efektif apabila tujuan anggaran tercapai dan bawahan memperoleh kesempatan terlibat atau berpartisipasi dalam proses penyusunan anggaran. Kinerja manajerial dapat memotivasi pegawai bawahan untuk mengidentifikasi dan melakukan negosiasi dengan pegawai atasan mengenai target anggaran, menerima kesepakatan anggaran dan melaksanakannya sehingga dapat menghindarkan dampak negatif anggaran yaitu faktor kriteria kinerja, sistem penghargaan (reward) dan konflik.

\section{Kerangka Pemikiran}

Keikutsertaan dan tanggung jawab yang dimiliki oleh pegawai OPD dalam proses penyusunan anggaran ini akan memunculkan perasaan bahwa kehadirannya dihargai oleh organisasinya sehingga akan memunculkan perasaan puas dalam diri bawahan tersebut karena masukannya dalam organisasi tersebut dihargai dan didengarkan. Kepuasan yang dimiliki oleh bawahan tersebut akan meningkatkan prestasi bawahan, dengan kata lain tingkat kinerja manajer akan meningkat.

Dalam penyusunan anggaran, bawahan akan menggunakan segala ide dan pemikirannya dalam menyusun anggaran tersebut. Untuk mencapai target anggaran yang telah disepakati tersebut bawahan harus lebih berinovasi dan memiliki ide kreatif untuk bisa mencapai target antara anggaran dengan realisasinya. Ketika target tersebut terpenuhi maka kinerja manajerial juga akan meningkat.Kerangka pemikiran penelitian dapat disajikan dalam gambar berikut ini: 


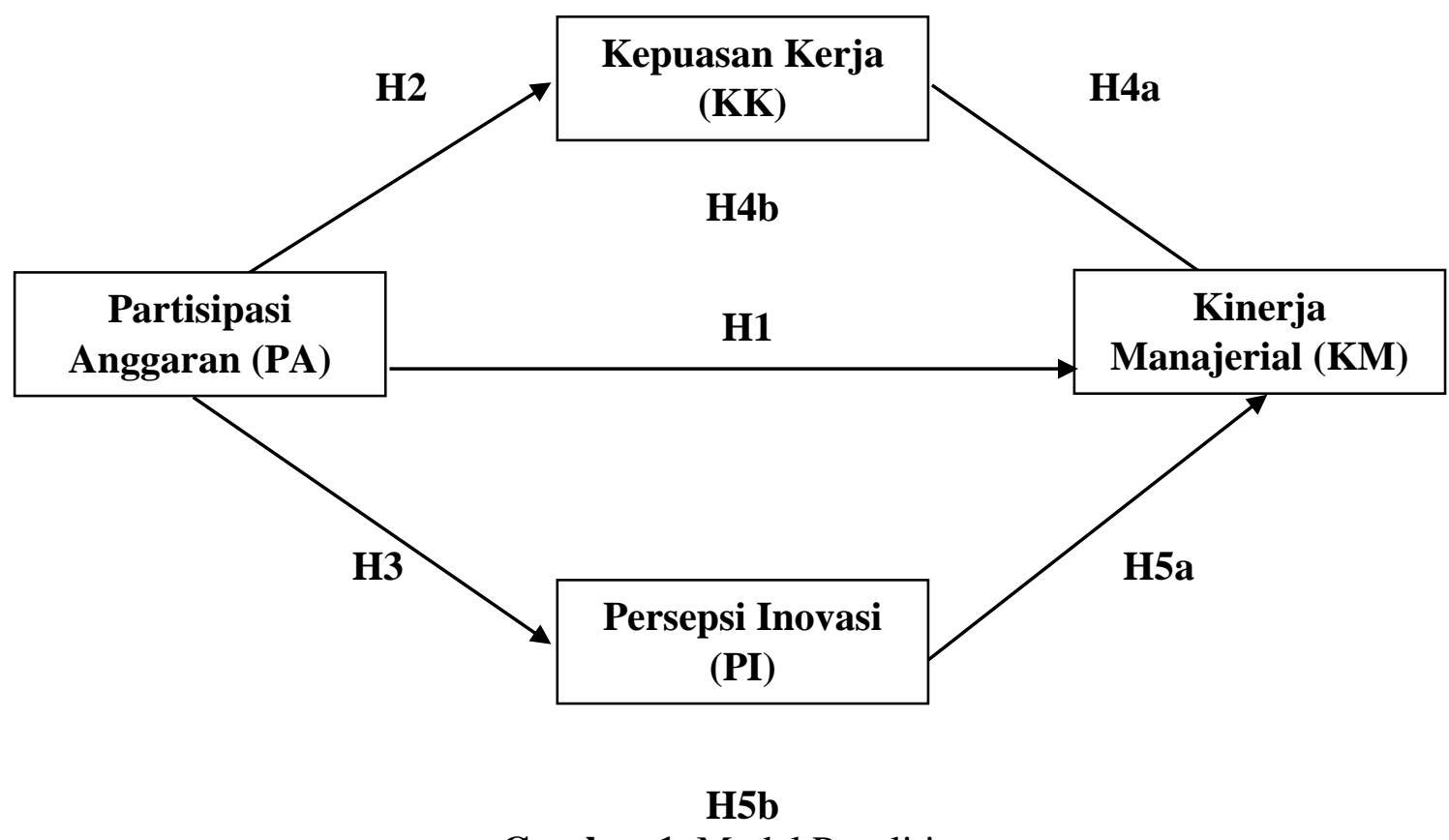

Gambar 1. Model Penelitian

Sumber: penelitian terdahulu oleh Ermawati (2012) dan Sukmantari danWiraseda (2015) yang dikembangkan oleh peneliti, 2016

\section{Hipotesis Penelitian}

Hipotesis penelitian yang diajukan dalam penelitian ini sebagai berikut:

Hipotesis 1: Partisipasi anggaran mempengaruhi kinerja manajerial.

Hipotesis 2: Partisipasi anggaran mempengaruhi kepuasan kerja.

Hipotesis 3: Partisipasi anggaran mempengaruhi persepsi inovasi.

Hipotesis 4a: Kepuasan kerja mempengaruhi kinerja manajerial.

Hipotesis 4b: Kepuasan kerja memediasi pengaruh antara partisipasi anggaran dan kinerja manajerial.

Hipotesis 5a: Persepsi inovasi mempengaruhikinerja manajerial.

Hipotesis 5b: Persepsi inovasi memediasi pengaruh antara partisipasi anggaran terhadap kinerja manajerial.

\section{METODE PENELITIAN}

\section{Populasi dan Sampel}

Populasi penelitian ini menggunakan metode non probability sampling dengan jenis sampling random sampling. Populasi yang digunakan dalam penelitian ini adalah OPD di Kabupaten Kudus sebanyak 43 OPD yang terdiri dari 12 dinas, 2 sekretariat, Inspektorat, RSUD, 3 badan, 6 kantor, 9 kecamatan dan 9 kelurahan. Dari 43 OPD tersebut terdapat 551 pejabat struktural yang terdiri dari kepala SKPD, sekretaris SKPD, kepala sub bagian/kepala sub bidang, dan kepala seksi dan staff keuangan yang memiliki peran dalam proses penyusunan anggaran.

\section{Teknik Pengumpulan Data}

Metode yang digunakan dalam melakukan pengumpulan data untuk melaksanakan penelitian adalah metode survey melalui pembagian kuesioner. Kuesioner merupakan teknik 
pengumpulan data yang dilakukan dengan cara memberi seperangkat pertanyaan tertulis kepada responden untuk dijawabnya. Data dikumpulkan melalui kuesioner yang diberikan kepada pegawai OPD dibagian keuangan OPD di Kabupaten Kudus.

\section{Alat Analisis Data}

Metode Pengujian Instrumen

Metode pengujian instrumen/kuesioner dalam penelitian ini menggunakan uji validitas dan uji Reliabilitas. Uji Reliabilitas untuk mengukur konsistensi kuesioner dalam mengukur suatu konstruk yang sama atau stabilitas kuesioner jika digunakan dari waktu ke waktu. Suatu konstruks atau variabel dikatakan reliabel jika memberikan nilai Cronbach Alpha lebih besar dari 0.6 (Yarnest: 67, 2004). Uji validitas digunakan untuk mengetahui kelayakan butir-butir dalam suatu daftar pernyataan dalam mendefinisikan suatu variabel. Instrumen dikatakan valid jika nilai > (Yarnest : 65, 2004).

\section{Uji Asumsi Klasik}

Uji asumsi klasik wajib terpenuhi sebelum dilakukan pengujian analisis regresi. Pengujian ini harus memenuhi uji Uji Normalitas, Uji Multikolinearitas, Uji Heteroskedastisitas.

\section{Uji Hipotesis}

Uji hipotesis yang digunakan dalam penelitian ini menggunakan Path Analysis. Path Analysis digunakan untuk menguji seberapa besar kontribusi yang diberikan oleh koefisien jalur antar variabel X1X2X3 terhadap Y serta dampaknya terhadap Z (Ghozali, 2005).

\section{HASIL PENELITIAN DAN PEMBAHASAN}

\section{Sampel Penelitian}

Responden yang digunakan dalam penelitian ini adalah pejabat yang menduduki jabatan sebagai Kepala/Sekretaris OPD, Kepala Bagian/Kepala Bidang, Kepala Subbagian, Kepala Seksi dan staff yang memiliki peran dalam proses penyusunan anggaran (RKA-OPD) sebagai tim penyusun anggaran. OPD yang ada di Kabupaten Kudus ini berjumlah 43 OPD dengan jumlah pegawai struktural sebesar 551, dengan menggunakan rumus Slovin didapatkan jumlah sampel sebesar 150. Jumlah kuesioner yang dibagikan ke responden sebanyak 150 untuk 43 OPD yang ada di Kabupaten Kudus. Dari hasil penyebaran kuesioner di dapatkan ada 108 responden yang bersedia mengisi kuesioner. Sebanyak 42 responden menolak untuk mengisi kuesioner dikarenakan kesibukan OPD.

\section{Hasil Uji Instrumen}

Uji Validitas

Instrumen dikatakan memenuhi Uji Validitas jika nilai signifikansi $<0,05$. Berikut ini hasil uji validitas :

\begin{tabular}{lccc} 
& \multicolumn{4}{c}{ Tabel 1. Hasil Uji Validitas } \\
\hline \multicolumn{1}{c}{ Variabel } & Item & Signifikansi & Keterangan \\
\hline Partisipasi Anggaran & PA & $\mathbf{0 , 0 0}$ & valid \\
Kepuasan Kerja & KK & $\mathbf{0 , 0 0}$ & valid \\
Persepsi Inovasi & P & $\mathbf{0 , 0 0}$ & valid \\
Kinerja Manajerial & KM & $\mathbf{0 , 0 0}$ & valid \\
\hline
\end{tabular}

Sumber: Data Primer Diolah, 2017

Berdasarkan tabel di atas menunjukkan bahwa nilai signifikansi di bawah 0,05, dapat 
disimpulkan bahwa instrument memenuhi uji validitas.

\section{Reliabilitas}

Reliabilitas ini dapat ditunjukkan dengan melihat nilai Cronbach Alpha lebih besar dari 0,60 (Cronbach Alpha > 0,60). Keempat variabel yang digunakan memiliki nilai Cronbach Alpha $>0,60$.

Tabel 2. Hasil Uji Reliabilitas

\begin{tabular}{lcc}
\hline \multicolumn{1}{c}{ Variabel } & Cronbach Alpha & Keterangan \\
\hline Partisipasi Anggaran & 0,731 & Reliabel \\
Kepuasan Kerja & 0,692 & Reliabel \\
Persepsi Inovasi & 0,757 & Reliabel \\
Kinerja Manajerial & 0,858 & Reliabel \\
\hline
\end{tabular}

Sumber: Data Primer Diolah, 2017

Berdasarkan tabel di atas menunjukkan instrumen memenuhi uji reliabilitas.

\section{Hasil Uji Asumsi Klasik}

Hasil Uji Normalitas

Data dikatakan normal jika nilai Kolmogorof Smirnov > 0,5. Berdasarkan Uji Kolmogorof Smirnov di dapatkan nilai siginifikansi 0,741. Hal ini menunjukkan bahwa nilai signifikansi > 0,5. Data yang digunakan terdistribusi normal. Berikut ini disajikan hasil uji normalitas data menggunakan Kolmogorof Smirnov:

Tabel 3. Hasil Uji Normalitas

\begin{tabular}{ccc}
\hline & & ABSOLUTE \\
\hline Normal Parameters $^{\mathrm{a}}$ & $\mathrm{N}$ & 99 \\
& Mean & $2.2328 \mathrm{E} 4$ \\
Most Extreme & Std. Deviation & $4.85758 \mathrm{E} 3$ \\
Differences & Absolute & .069 \\
& Positive & .065 \\
Kolmogorov-Smirnov Z & -.069 \\
Asymp. Sig. (2-tailed) & .682 \\
\hline
\end{tabular}

Sumber: Data Primer diolah, 2017

\section{Hasil Uji Multikolinieritas}

Data dikatakan bebas dari Multikolinieritas jika nilai tolerance $>0,1$ dan nilai VIF $>1$. Berdasarkan tabel 4 di dapatkan variabel Partisipasi Anggaran, Kepuasan Kerja, Persepsi Inovasi memiliki nilai tolerance $>0,1$ dan nilai $\mathrm{VIF}>1$. Hal ini menunjukkan bahwa data terbebas dari Multikolinieritas. Berikut ini disajikan hasil uji Multikolinieritas: 
Tabel 4. Hasil Uji Multikolinieritas

\begin{tabular}{|c|c|c|c|c|c|c|c|c|}
\hline \multirow[b]{2}{*}{ Model } & & $\begin{array}{l}\text { Unstand } \\
\text { Coeffic }\end{array}$ & $\begin{array}{l}\text { ardized } \\
\text { cients }\end{array}$ & $\begin{array}{c}\text { Standardize } \\
\mathrm{d} \\
\text { Coefficients }\end{array}$ & \multirow[b]{2}{*}{$\mathrm{t}$} & \multirow[b]{2}{*}{ Sig. } & \multicolumn{2}{|c|}{ Collinearity Statistics } \\
\hline & & $\mathrm{B}$ & $\begin{array}{l}\text { Std. } \\
\text { Error }\end{array}$ & Beta & & & Tolerance & VIF \\
\hline 1 & $\begin{array}{l}\text { (Consta } \\
\text { nt) }\end{array}$ & 21.697 & 5.599 & & 3.875 & .000 & & \\
\hline & PA & .214 & .183 & .155 & 1.167 & .246 & .531 & 1.882 \\
\hline & KK & -.193 & .137 & -.187 & -1.404 & .164 & .533 & 1.876 \\
\hline & PI & .460 & .169 & .268 & 2.718 & .008 & .970 & 1.031 \\
\hline
\end{tabular}

a. Dependent Variable:

KM

Sumber: Data primer diolah, 2017

Berdasarkan tabel di atas menunjukkan bahwa data terbebas dari multikolinieritas.

\section{Hasil Uji Heteroskedastisitas}

Data dikatakan terbebas dari Heteroskedastisitas jika nilai Signifikansi $>0,05$. Berdasarkan tabel 11 didapatkan masing masing variabel Independen yaitu Partisipasi Anggaran, Kepuasan Kerja dan Persepsi Inovasi memiliki nilai signifikansi 1,00. Hal ini menunjukkan bahwa nilai signifikansi $>0,05$. Data yang digunakan dalam penelitian ini terbebas dari Heteroskedastisitas.

Berikut ini hasil Uji Glejser :

Tabel 5. Hasil Uji Heterokedastisitas - Uji Glejser

Standardiz

ed

Unstandardized Coefficien

Collinearity

Coefficients ts

Std.

Statistics

Model

B Error Beta $t$ Sig. e

1 (Constant) -1.830E-

155.599

$.000 \quad 1.000$

PA

$.000 \quad .183$

$\begin{array}{lll}.000 & 000 & 1.000\end{array}$

$.531 \quad 1.882$

PI

$.000 \quad .169$

$.000 \quad .000 \quad 1.000$

$.970 \quad 1.031$

KK

$.000 \quad .137$

$\begin{array}{lll}.000 & 000 & 1.000\end{array}$

$.533 \quad 1.876$

a. Dependent Variable: ABS_RES

Sumber : Data Primer Diolah, 2017 
Hasil Uji Path Analysis

Berikut ini hasil uji Path Analysis:

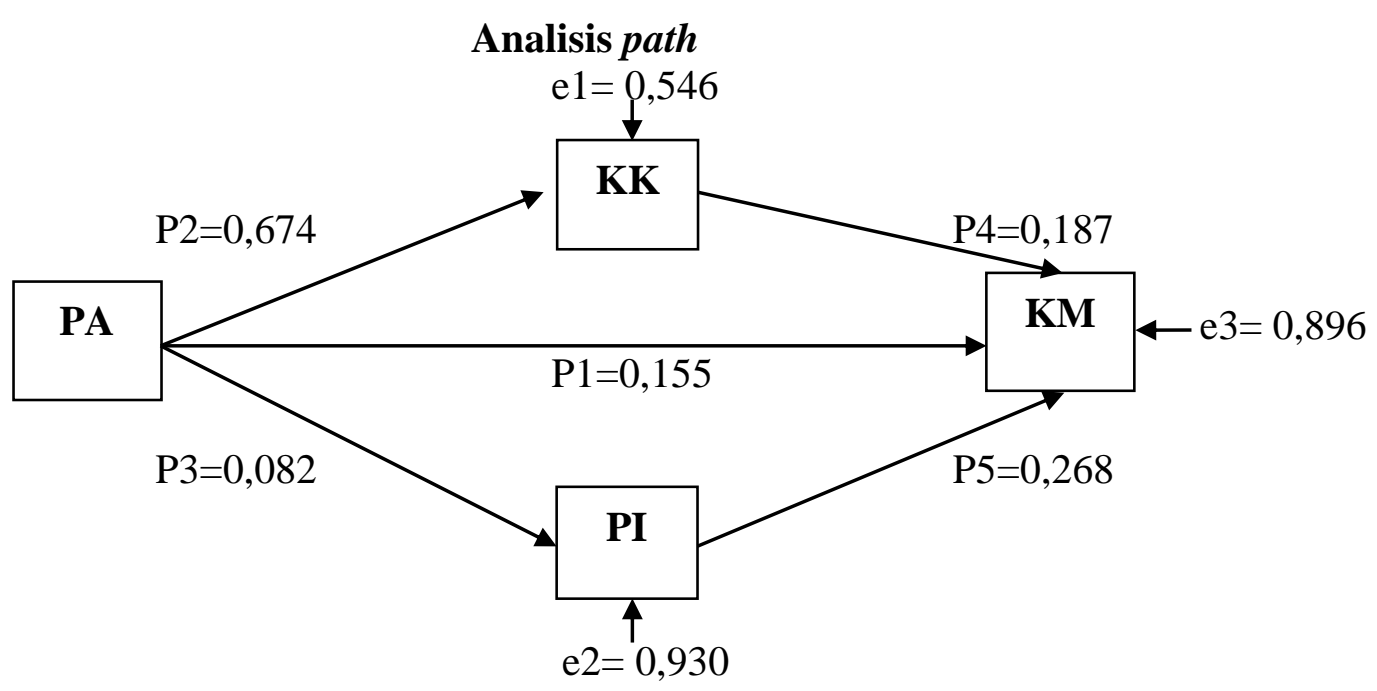

Gambar 2. Analisis Path

Sumber: Data Primer Diolah, 2017

Berdasarkan gambar 2 di atas menunjukkan bahwa partisipasi anggaran dapat berpengaruh secara langsung terhadap kinerja manajerial. Namun secara analisis Path ditarik kesimpulan bahwa baik kepuasan kerja maupun persepsi inovasi tidak mampu memediasi pengaruh antara partisipasi anggaran terhadap kinerja manajerial.

\section{Pembahasan}

Ringkasan hasil Uji Hipotesis disajikan dalam tabel sebagai berikut :

Tabel 6. Ringkasan Hasil Uji Hipotesis

\begin{tabular}{|c|c|c|c|}
\hline \multirow{2}{*}{\multicolumn{2}{|c|}{ Hipotesis }} & \multicolumn{2}{|c|}{ Keterangan } \\
\hline & & Sig & Kesimpulan \\
\hline H1 & $\begin{array}{l}\text { partisipasi anggaran berpengaruh positif } \\
\text { terhadap kinerja manajerial }\end{array}$ & $0,046<0,05$ & Diterima \\
\hline $\mathrm{H} 2$ & $\begin{array}{l}\text { partisipasi anggaran berpengaruh positif } \\
\text { terhadap kepuasan kerja }\end{array}$ & $0,000<0,05$ & Diterima \\
\hline H3 & $\begin{array}{l}\text { partisipasi anggaran berpengaruh positif } \\
\text { terhadap persepsi inovasi }\end{array}$ & $0,022<0,05$ & Diterima \\
\hline $\mathrm{H} 4 \mathrm{a}$ & $\begin{array}{l}\text { Kepuasan kerja berpengaruh positif terhadap } \\
\text { kinerja manajerial }\end{array}$ & $0,040<0,05$ & Diterima \\
\hline $\mathrm{H} 4 \mathrm{~b}$ & $\begin{array}{l}\text { Kepuasan kerja memediasi hubungan antara } \\
\text { partisipasi anggaran dan kinerja manajerial }\end{array}$ & $0,155>0,126$ & Ditolak \\
\hline H5a & $\begin{array}{l}\text { Persepsi inovasi berpengaruh positif terhadap } \\
\text { kinerja manajerial }\end{array}$ & $0,008<0,05$ & Diterima \\
\hline $\mathrm{H} 5 \mathrm{~b}$ & $\begin{array}{l}\text { Persepsi inovasi memediasi hubungan antara } \\
\text { partisipasi anggaran terhadap kinerja } \\
\text { manajerial }\end{array}$ & $0,155>0,021$ & Ditolak \\
\hline
\end{tabular}

Sumber: Data Primer Diolah, 2017 


\section{Partisipasi Anggaran dan Kinerja Manajerial}

Berdasarkan hipotesis 1 menunjukkan nilai signifikansi sebesar 0,046. Hal ini menunjukkan bahwa nilai $0,046<0,05$, dapat ditarik kesimpulan bahwa hipotesis 1 diterima. Dengan demikian partisipasi anggaran dapat berpengaruh secara langsung terhadap kinerja manajerial. Hipotesis 1 diterima dapat dilihat dari tingkat partisipasi anggaran yang tinggi oleh OPD Kabupaten Kudus. Tingginya tingkat partisipasi anggaran oleh OPD Kabupaten Kudus ini dapat dilihat dari tingginya jawaban responden dalam menjawab kuesioner, dimana nilai mean yang tinggi yaitu sebesar 25,37.

Dalam penyusun anggaran, Pemerintah Kabupaten Kudus melibatkan aparat pemerintah dari level yang paling rendah sampai dengan level yang tinggi. Begitu juga dengan proses penyusunan anggaran pada OPD Kabupaten Kudus, juga melibatkan pihak staff, kepala bagian, kepala bidang sampai dengan kepala OPD. Semua pegawai dalam OPD tersebut dilibatkan dalam proses penyusunan anggaran dengan alasan pihak bawahan yang lebih mengetahui tentang kebutuhan yang ada di lapangan. Dengan dilibatkannya pihak bawahan dalam menyusun anggaran akan tercapainya anggaran yang disusun. Antara anggaran dengan realisasi akan sesuai. Dengan tingginya keterlibatan pihak bawahan dalam menyusun anggaran ini, program kerja dan target anggaran dapat terserap sesuai dengan anggaran yang telah disusun.

Hasil penelitian ini konsisten dengan penelitian yang telah dilakukan oleh Yahya.et.al (2008), Nurcahyani (2010), Ermawati (2012), Widyanto, (2012), Fitrianti \& Marbawi (2013), Muharrom (2014), Safriadi .et.al (2015), Sukmantari \& Wirasedana (2015), yang menunjukkan bahwa partisipasi anggaran berpengaruh terhadap kinerja manajerial. Pegawai OPD yang dilibatkan dalam proses penyusunan anggaran ini akan bekerja dengan sebaik mungkin sehingga kinerja manajerial OPD meningkat. Namun penelitian ini tidak sejalan dengan penelitian yang telah dilakukan oleh Palebangan (2012), yang menunjukkan bahwa pegawai OPD yang dilibatkan dalam proses penyusunan anggaran tidak menunjukkan kenaikan kinerja manajerial. Hal ini dikarenakan pegawai OPD dalam menyusun anggaran sekedar untuk menyusun anggaran karena memang sudah kewajiban. Sehingga tidak ada pengaruhnya terhadap kinerja manajerial OPD.

\section{Partisipasi Anggaran dan Kepuasan Kerja}

Berdasarkan hipotesis 2 menunjukkan nilai signifikansi sebesar 0,000. Hal ini menunjukkan bahwa nilai $0,000<0,05$, dapat ditarik kesimpulan bahwa hipotesis 2 diterima. Hal ini menunjukkan bahwa partisipasi anggaran dapat berpengaruh positif terhadap kepuasan kerja. Hipotesis 2 diterima juga dapat dilihat dari tingginya tingkat kepuasan kerja karyawan di lingkungan OPD Kabupaten Kudus yaitu dengan tingginya nilai mean/nilai ratarata kepuasan kerja yaitu sebesar 37,44. Pegawai OPD yang dilibatkan dalam menyusun anggaran ini akan merasa puas terhadap pekerjaannya. Hal ini disebabkan karena pegawai OPD ini merasa ide dan kerja kerasnya dihargai oleh instansi tempat mereka bekerja. Dengan merasa dihargainya ide ide yang telah di berikan tersebut akan membuat pegawai tersebut merasa nyaman dengan pekerjaannya. Kondisi lingkungan kerja yang nyaman inilah yang menyebabkan pegawai merasa puas dengan pekerjaan yang telah dilakukan.

Hasil penelitian ini konsisten dengan penelitian yang telah dilakukan oleh Fitrianti \& Marbawi (2013), Sukmantari \& Wirasedana (2015).

\section{Partisipasi Anggaran dan Persepsi Inovasi}

Berdasarkan hipotesis 3 menunjukkan bahwa nilai signifikansi $0,022<0,05$. Dapat disimpulkan bahwa hipotesis 3 dapat diterima, yang menunjukkan partisipasi anggaran dapat berpengaruh positif terhadap persepsi inovasi. 
Dengan adanya partisipasi anggaran, pegawai OPD akan dilibatkan dalam proses penyusunan anggaran. Level staff, kepala bidang, kepala bagian, kepala OPD akan terlibat secara bersama-sama dalam menyusun anggaran. Dalam menyusun anggaran ini tidak sekedar mengajukan dana yang akan digunakan untuk OPD tersebut selama satu tahun yang akan datang. Disinilah pentingnya keterlibatan bawahan dalam menyusun anggaran. Dalam menyusun anggaran ini semua pihak harus menggunakan semua ide yang dimiliki untuk menghasilkan anggaran yang sesuai dengan kebutuhan OPD tersebut untuk satu tahun yang akan datang.

Ide kreatif dalam menyusun anggaran ini diperlukan untuk menentukan berapa besarnya alokasi anggaran pendapatan dan anggaran belanja. Besarnya alokasi anggaran ini disesuaikan dengan tugas dan fungsi masing-masing OPD. Kepandaian yang dimiliki oleh pegawai dalam menyusun anggaran ini disebut persepsi inovasi. Pegawai OPD yang tidak mampu memahami antara peraturan dengan praktik penyusunan anggaran maka pegawai tersebut kurang inovatif. Dengan tepatnya penyusunan alokasi anggaran ini tidak akan ada anggaran yang berlebih atau kekurangan anggaran.

Pentingnya pihak bawahan dilibatkan dalam proses penyusunan anggaran ini menimbulkan ide kreatif pihak bawahan akan meningkat. Dengan ide kreatif yang dimiliki oleh pihak bawahan dalam menentukan porsi anggaran yang tepat inilah menunjukkan persepsi inovasi anggota OPD Kabupaten Kudus Tinggi.

Hasil penelitian ini konsisten dengan penelitian yang telah dilakukan oleh Nurcahyani (2010), Ermawati (2012), Palebangan (2012), Widyanto, (2012), Fitrianti \& Marbawi (2013), yang menunjukkan bahwa partisipasi anggaran berpengaruh terhadap persepsi inovasi. Pegawai OPD yang dilibatkan dalam penyusunan anggaran akan memunculkan ide kreatif yang dimilikinya karena pegawai akan menyesuaikan antara peraturan pemerintah dengan kebutuhan yang ada di OPD. Namun penelitian ini tidak sejalan dengan penelitian yang telah dilakukan oleh Yahya.et.al (2008), Muharrom (2014), Safriadi .et.al (2015), yang menunjukkan bahwa partisipasi anggaran tidak mampu mempengaruhi persepsi inovasi.

\section{Partisipasi Anggaran, Kepuasan Kerja, Kinerja Manajerial}

Berdasarkan hipotesis 4a menunjukkan nilai signifiknasi sebesar 0,040. Hal ini menunjukkan bahwa nilai 0,040 < 0,05, menunjukkan bahwa hipotesis 4a dapat diterima. Diterimanya hipotesis 4a dapat disimpulkan bahwa kepuasan kerja dapat berpengaruh secara positif terhadap kinerja manajerial.

Pegawai OPD yang merasa puas dengan pekerjaan yang dilakukan akan bekerja dengan sebaik mungkin. Dengan bekerja sebaik mungkin ini akan menghasilkan kinerja yang bagus untuk instansinya. Kepuasan kerja juga merupakan suatu hal yang membuat pegawai OPD merasa nyaman dengan tempat dia bekerja. Selain merasa nyaman, pegawai OPD juga merasa senang dengan keterlibatannya dalam menyusun anggaran. Suatu pekerjaan jika dikerjakan dengan senang akan menghasilkan output yang bagus.

Pegawai OPD yang dilibatkan dalam penyusunan anggaran akan menciptakan moral kerja dan inisiatif kerja yang tinggi (Fitrianti \& Marbawi, 2013). Moral kerja yang tinggi merupakan kepuasan seseorang terhadap pekerjaan yang dijalankan. Pegawai OPD yang puas atas pekerjaan yang dijalankan ini akan meningkatkan kinerja manajerial. Dengan kata lain, ketika pegawai OPD memiliki kepuasan kerja yang tinggi akan menghasilkan kinerja manajerial yang tinggi juga. Hasil penelitian ini konsisten dengan penelitian yang telah dilakukan oleh Fitrianti \& Marbawi (2013), Sukmantari \& Wirasedana (2015).

Hipotesis 4b menunjukkan bahwa kepuasan kerja memediasi hubungan antara partisipasi anggaran dan kinerja manajerial. Untuk melihat hubungan tersebut dapat dilakukan dengan membandingkan pengaruh langsung dengan pengaruh tidak langsung. pengaruh langsung dapat dilihat dari besarnya nilai koefisien path antara partisipasi anggaran terhadap kinerja 
manajerial yaitu sebesar 0,155 . Sedangkan pengaruh tidak langsung dapat dihitung dengan besarnya perkalian koefisien path partisipasi anggaran terhadap kepuasan kerja (p2) dengan koefisien path kepuasan kerja terhadap kinerja manajerial (p4). Hasil perkalian sebesar 0,126. Perbandingan koefisien path secara langsung dan tidak langsung yaitu 0,155 dengan 0,126. Hal ini menunjukkan bahwa 0,155 > 0,126, dapat disimpulkan bahwa kepuasan kerja tidak mampu memediasi hubungan antara partisipasi anggaran terhadap kinerja manajerial.

Hasil penelitian ini konsisten dengan penelitian yang telah dilakukan oleh Fitrianti \& Marbawi (2013), yang menunjukkan bahwa kepuasan kerja tidak mampu memediasi pengaruh antara partisipasi anggaran terhadap kinerja manajerial. Namun penelitian ini tidak sejalan dengan penelitian yang telah dilakukan oleh Sukmantari \& Wirasedana (2015), yang menunjukkan bahwa kepuasan kerja mampu memediasi pengaruh partisipasi anggaran terhadap kinerja manajerial.

\section{Partisipasi Anggaran, Persepsi Inovasi, Kinerja Manajerial}

Berdasarkan pengujian hipotesis 5a, didapatkan nilai signifikansi sebesar 0,008. Pengujian ini berfungsi untuk melihat pengaruh antara persepsi inovasi terhadap kinerja manajerial. Dimana nilai signifikansi $0,008<0,05$, hal ini membuktikan bahwa persepsi inovasi berpengaruh terhadap kinerja manajerial. Persepsi inovasi yang tinggi ini akan meningkatkan kinerja manajerial. Tingginya tingkat persepsi inovasi karyawan di OPD Kabupaten Kudus ini dapat dilihat dari tingginya nilai mean yang didapatkan dari jawaban responden dalam mengisi kuesioner yang dibagikan. Nilai mean yang tinggi ini sebesar 23,28 .

Persepsi inovasi dapat dilihat dari bagaimana pegawai OPD dapat memecahkan masalah dalam penyusunan anggaran. Pegawai OPD yang inovatif, mereka akan berusaha menyusun anggaran yang sesuai dengan kebutuhan yang di butuhkan oleh instansi tempat mereka bekerja. Dengan kepandaian yang dimilikinya akan menghasilkan anggaran yang tepat dan sesuai dengan program kerja masing masing OPD. Ketepatan dalam penyusunan anggaran ini akan berakibat dengan prestasi OPD yang baik. Prestasi OPD yang baik ini mengindikasikan bahwa kinerja manajerial OPD tersebut juga meningkat. Hasil penelitian ini konsisten dengan penelitian yang telah dilakukan oleh Ermawati (2012), Palebangan (2012), Widyanto, (2012), Muharrom (2014), Safriadi .et.al (2015), yang menunjukkan bahwa persepsi inovasi mampu memediasi pengaruh partisipasi anggaran terhadap kinerja manajerial. Namun penelitian ini tidak sejalan dengan penelitian yang telah dilakukan oleh Yahya.et.al (2008), Nurcahyani (2010), yang menunjukkan persepsi inovasi tidak mampu memediasi pengaruh partisipasi anggaran terhadap kinerja manajerial.

Untuk menguji hipotesis $5 \mathrm{~b}$ yaitu, persepsi inovasi memediasi hubungan antara partisipasi anggaran terhadap kinerja manajerial. Untuk melihat hubungan tersebut dapat dilakukan dengan membandingkan pengaruh langsung dengan pengaruh tidak langsung. pengaruh langsung dapat dilihat dari besarnya nilai koefisien path antara partisipasi anggaran terhadap kinerja manajerial yaitu sebesar 0,155. Sedangkan pengaruh tidak langsung dapat dihitung dengan besarnya perkalian koefisien path partisipasi anggaran terhadap persepsi inovasi (p3) dengan koefisien path persepsi inovasi terhadap kinerja manajerial (p5). Hasil perkalian sebesar 0,021. Perbandingan koefisien path secara langsung dan tidak langsung yaitu 0,155 dengan 0,021 . Hal ini menunjukkan bahwa $0,155>0,021$, dapat disimpulkan bahwa persepsi inovasi tidak mampu memediasi hubungan antara partisipasi anggaran terhadap kinerja manajerial.

Hasil penelitian ini konsisten dengan penelitian yang telah dilakukan oleh Fitrianti \& Marbawi (2013). Namun penelitian ini tidak sejalan dengan penelitian yang telah dilakukan oleh Sukmantari \& Wirasedana (2015). 


\section{KESIMPULAN}

Dari hasil analisis data dan pembahasan penelitian ini, dapat disimpulkan bahwa : 1). Partisipasi anggaran dapat berpengaruh secara langsung terhadap kinerja manajerial OPD Kabupaten Kudus, 2). Partisipasi anggaran dapat berpengaruh positif terhadap kepuasan kerja OPD Kabupaten Kudus, 3). Partisipasi anggaran dapat berpengaruh positif terhadap persepsi inovasi OPD Kabupaten Kudus, 4). Kepuasan kerja dapat berpengaruh secara positif terhadap kinerja manajerial OPD Kabupaten Kudus, 5). Persepsi inovasi berpengaruh terhadap kinerja manajerial OPD Kabupaten Kudus, 7). Kepuasan kerja tidak mampu memediasi hubungan antara partisipasi anggaran terhadap kinerja manajerial OPD Kabupaten Kudus, 7). Persepsi inovasi tidak mampu memediasi hubungan antara partisipasi anggaran terhadap kinerja manajerial OPD Kabupaten Kudus.

\section{DAFTAR PUSTAKA}

Anthony dan Govindarajan, (2005). Management System. Terjemahan. Jakarta: Salemba Empat.

Borins, S. (2001). Encouraging Innovation in the Public Sector. Journal of Intellectual Capital. 2(3), 310-9.

Brownell. P. and McInnes, M. (1986). Budgetary Participation, Motivation, and Manajerial Performance. The Accounting Review, 61(4).

Cong Vinchent K \& Kar Ming Chong. (2002). Budget Goal Commitment and Informational Effects of Budget Participation on Performance, Astructural Equation Modeling Approach. Journal of Accounting Research, 65-68.

Coryanata. (2004). Pelimpahan Wewenang dan Komitmen Organisasi dalam Hubungan antara Partisipasi Penyusunan Anggaran dan Kinerja Manajerial. Disampaikan pada Simposium Nasional Akuntansi (SNA) VII. Denpasar, 2-3 Desember 2004.

Damanpour, F., Szabat, K. A., \& Evan, W. M. 1989. The Relationship between types of Innovation and Organizational Performance. Journal of Mangagement Studies, 26(6), $587-601$

Davis, K dan J. W. 1985. Organizational Behaviour: Human Behaviour at Work. Seven Edition. Singapore: Mc Graw, Inc.

Deputi IV BPKP. (2015). Retrieved from: http://www.bpkp.go.id/sakd.bpkp

Ermawati Nanik. (2012). Pengaruh Partisispasi Anggaran Terhadap Kinerja Manajerial: Komitmen Organisasi dan Persepsi Inovasi Sebagai Variabel Intervening (Studi Kasus Pada SKPD Kabupaten Pati). Thesis. Universitas Diponegoro. Semarang. Tidak dipublikasi.

Fitrianti Mastura \& Marbawi. (2013). Pengaruh Partisipasi Penyusunan Anggaran terhadap Kinerja Manajerial dengan Variabel Intervening Motivasi dan Kepuasan Kerja pada SETDAKAB Aceh Utara. Jurnal. Unimal.

Ghozali, Imam. 2005. Aplikasi Analisis Multivariate dengan program SPSS. Badan Penerbit Universitas Diponegoro. Semarang.

Hansen dan Mowen, 2004. Akuntansi Manajemen. Edisi Ketujuh. Penerbit: Salemba Empat. Jakarta.

Herzberg, 2005. Motivation Theory. Journal of Management Development, 24.

Kantor Kesatuan Bangsa \& Politik Kabupaten Kudus, 2016

Kurnia. 200. Pengaruh Stuktur dan Kultur Organisasional terhadap keefektifan Anggaran Partisipatif dalam Penigkatan Kinerja Manajerial: Studi Empiris pada Perusahaan 
Manufaktur di Indonesia. Skripsi. No.18/VII,61-84.

Kreitner R dan Kinicki, A. 2001. Organizational Behaviour. Fifth Edition. Internasional

Edition. Mc graw-Hill Companies. Inc.

Luthans, F. 1995. Organizational Behaviour: Seven Edition. Singapore: McGraw-Hill, Inc.

Leach-Lopez, M.A.,W.W. Stammerjohan, F.M.McNair. 2007. Differences in the Role of Job-Relevant Information in the Budget Participation- Performance Relationship among U.S.and Mexican Managers: A Question of Culture or Communication. Journal of Management Accounting Research, 19(2), 105-136.

Mardiasmo. 2002. Akuntansi Sektor Publik. Edisi II. Penerbit Andi. Yogyakarta.

Muhammad, Arni, 2007. Komunikasi Organisasi. Bumi Aksara, Jakarta.

Mulyadi. 1993. Akuntansi Biaya Edisi 5. Yogyakarta: STIE YKPN.

Munandar, M. 2001. Budgetting, Perencanaan Kerja Koordinasian Kerja dan Pengawasan Kerja. Edisi 2. Yogyakarta.

Mahoney,T.A., Jerdes, T.H. and Carroll, S.J. (1963). Development Managerial Performance: a Research Approach. Southwestern Publishing Co.

Margareth dan Halim. (2005). Pengaruh Partisipasi Manajer Dalam Penyusunan Anggaran Terhadap Kepuasan Kerja dan Kinerja Manajerial. Skripsi. Universitas Petra. Surabaya.

Nasution. 2007. Ketua Badan Pemeriksa Keuangan (BPK)

Nurcahyani, Kunwaviyah. (2010). Pengaruh Partisipasi Anggaran terhadap Kinerja Manajerial. Skripsi. Universitas Diponegoro. Semarang.

Robbins, Stephen. P. (1996). Perilaku Organisasi: Konsep, Kontroversi, Aplikasi, Edisi Bahasa Indonesia. PT. Prenhallindo. Jakarta.

Robbins, Stephen. P. (2003). Perilaku Organisasi. Jilid 2. PT. Indeks Kelompok Gramedia. Jakarta.

Robbins, Stephen. P. (2006). Perilaku Organisasi. Edisi Kesepuluh. Jakarta: PT. Indeks Kelompok Gramedia.

Siegel, G. Marconi. (1989). Behavioral Accounting. South Western Publishing Co. Second Edition.

Sukmantari Dewa Ayu Made Harlista Sukmantari, Wirasedana I Wayan Pradnyantha. 2015. Pengaruh Partisipasi Penganggaran Dan Komitmen Organisasi Pada Kinerja Manajerial Dengan Kepuasan Kerja Sebagai Variabel Intervening. E-Jurnal Akuntansi Universitas Udayana, 10.1 (2015): 261- ISSN: 2302 - 8556

Subramaniam, N. and Ashkanasy,N. (2001). The Effect of Organizational Culture Perseptions between Budgetary Participation and Manajerial Job-Related Incomes. Australian Journal of Management, 26(1), 35-55.

Subramaniam, N. And Mia, L. (2003). "The Effect of Organizational Commitment: The Role of Perception of Equity. Advances on Accounting Behavioural Research, 4.

Sujarweni, Wiratna. (2014). SPSS Untuk Penelitian. Yogyakarta: Pustaka Baru Press.

Sumarno, J. (2005). Pengaruh Komitmen Organisasi dan Gaya Kepemimpinan Terhadap Hubungan Antara Partisipasi Anggaran dan Kinerja Manajerial. Jurnal. SNA VIII. Solo.

Sord. Welsch. (1995). Anggaran, Perencanaan dan Pengendalian Laba Buku Satu, Edidi Kelima, Jakarta: Salemba Empat.

Williams, J.J., Macintosh, N.B. and Morce, I.C. (1990). Budget Related Behavior in Public Sector Organizations: Some Empirical Evidence. Accounting, Organizations and Society, 15(3), 221-46.

Wright, Sewall. (1934). Statistical Genetics and Evolution. Bull. Amer. Math. Soc. 48(4): 223-246.

Yarnest. (2004). Panduan Aplikasi Statistik dengan Bantuan SPSS versi 11.0. Penerbit Percetakan Dioma. Malang.

Yahya Nor Mohd, Nik Nazli Nik Ahmad, Abdul Hamid Fatima. (2008). Budgetary 
participation and performance: some Malaysian evidence. International Journal of Public Sector Management, 21(6), 658-673. Emerald Group Publishing Limited 09513558 DOI 10.1108/09513550810896523. 